\title{
“O DIVINO” VERSUS O DIVINO: O MARQUÊS DE SADE E A CRÍTICA À RELIGIÃO
}

\author{
Stefani Arrais Nogueira \\ Orientação: Ana Paula Vosne Martins
}

PALAVRAS-CHAVE: literatura libertina; ateísmo sadiano; Natureza.

O século XVIII pode ser entendido, pelo menos na Europa, como o século das Luzes, do Iluminismo e, nessa perspectiva, a França tem sido considerada um dos seus mais importantes centros de produção cultural e do pensamento. Não obstante, é nesse ambiente que temos também o florescimento de um gênero literário que foi de suma importância na propagação dos valores iluministas para um público numericamente mais relevante.

Aliás, é na escrita que se trafega o ideário iluminista, como explica Pierre Chaunu ${ }^{1}$, é através da escrita, em todas as suas formas, que se concretizam e se transmitem as idéias das Luzes. Dessa forma, nada mais natural do que vestir esse ideário de uma literatura que através da ficção a liberta dos rigores filosóficos. Falamos assim, da literatura libertina.

No século XVII uma literatura libertina já começa a aparecer na cena cultural francesa. No seu conteúdo já podemos notar tanto uma descrença de credos religiosos, quanto uma estilização erótica e subversiva. O próprio "título" de libertino era dado àqueles escritores e pensadores que se manifestavam de forma contrária à moral religiosa. Todavia, mesmo que dotado dessa característica contestadora, é só no século seguinte, que a identidade do libertino vai se tornar mais fortemente anti-religiosa por vincular-se definitivamente ao ateísmo.

Somado ao ateísmo dos libertinos do século XVIII, temos outra característica que irá marcar profundamente o seu

\footnotetext{
${ }^{1}$ CHAUNU. Pierre. A civilização da Europa das Luzes Vol. I; Tradução Manuel João Gomes. Lisboa; Editorial Estampa 1985.
} 
entendimento, isto é, a ligação entre libertinagem e transgressões morais e sexuais. Isso nos leva a pensar que inicialmente os libertinos se caracterizavam pelo desafio aos dogmas da religião e à autoridade do poder, com o passar do tempo, eles vão substituindo a rebeldia política e religiosa pela afronta à moral ${ }^{2}$

A literatura libertina, segundo Rouanet ${ }^{3}$, devido a sua própria natureza menos séria e respingada de humor, foi um excelente instrumento para a divulgação dos ideais iluministas. As idéias dos filósofos das Luzes foram diluídas de sua austeridade e se propagaram com mais facilidade nos contos satíricos e eróticos.

É justamente nesse ponto que podemos localizar nosso personagem, Donatien Alphonse-François de Sade (1740-1814), mais conhecido como o Marquês de Sade. Sua obra, assim como a de vários outros escritores libertinos de sua época, serviu como condutora e catalisadora dos ideais iluministas. Todavia, particularidades são as características que mais se sobressaem no Marquês.

Um dos mais importantes valores das Luzes é a liberdade, liberdade do homem e da sua mente através da razão. Dessa forma, para Kant, o Iluminismo ou Aufklärung seria a saída do homem de sua menoridade da qual ele próprio é culpado. Um dos impedimentos à maioridade do homem seriam as superstições e preconceitos difundidos pela religião. Dessa forma, a religião torna-se um dos maiores focos que a crítica iluminista e, conseqüentemente, a crítica libertina se concentra.

Esse papel de crítico da religião foi bem desempenhado por Sade, no entanto, a peculiaridade mencionada furtivamente acima se fundamenta no caráter de sua obra. Rouanet afirma que Sade, apesar de divulgar os valores das Luzes em sua obra, o fez quase que às avessas, promovendo um Contra-Iluminismo. Isso se aplica em quase

\footnotetext{
${ }^{2}$ MORAES. Eliane Robert. Lições de Sade: ensaios sobre a imaginação libertina. São Paulo: Iluminuras, 2006, p. 79.

${ }^{3}$ ROUANET. Sergio Paulo. O desejo libertino entre o iluminismo e o contrailuminismo; In: NOVAES. Adauto. O Desejo. São Paulo: Cia. das Letras, 1990.
} 
todos os preceitos do Iluminismo. No quesito religião, a crítica se faz de forma bastante ferrenha e imbuída da crueldade específica de sua Filosofia do Mal.

O objeto dessa pesquisa é justamente a crítica libertina presente na literatura erótica e satírica na qual Sade ocupa um lugar bem específico por não se encaixar em nenhuma corrente filosófica propriamente dita.

O conjunto de fontes utilizado neste trabalho englobou duas obras completas do Marquês de Sade (Justine, ou os infortúnios da virtude e A Filosofia na Alcova) e um conjunto de textos e extratos de outras obras suas publicadas em uma única edição intitulada Diálogo entre um padre e um moribundo e outras diabrites $e$ blasfêmias.

Para a análise das obras sadianas foi necessário extrair dos textos as principais linhas discursivas que denotavam o deboche e a crítica do autor as crenças religiosas. Foi esquematizado um fichário temático onde se destacou os pensamentos do autor a respeito da religião e da idéia de natureza.

Passada essa etapa utilizamos os conceitos-chave que contribuíram para o entendimento do texto. Trabalhou-se com o conceito de erotismo empregado por Georges Bataille ${ }^{4}$, por esse estabelecer uma relação entre percepções do erotismo sensual e o pensamento religioso. Também o conceito de crítica empregado por Reinhard Koselleck ${ }^{5}$ se fez necessário por instituir como intuito primário da crítica a busca pela verdade.

A partir da leitura e da análise dessas obras do Marquês de Sade foi possível notar a forma extremada do discurso sadiano no ataque às crenças religiosas. Também foi possível perceber as diversas influências literárias, sociais, históricas e filosóficas

\footnotetext{
${ }^{4}$ BATAILLE, G. O Erotismo. Tradução de Antonio Carlos Viana. Porto Alegre: L\&PM, 1987. $2^{\mathrm{a}}$ ed.

5 KOSELlECK, R. Critica e crise. Tradução de Luciana Vilas-Boas Castelo Branco. São Paulo: Contraponto, 1999.
} 
recebidas pelo autor e como ele se utilizou destas para legitimar sua própria filosofia.

A monografia está composta de três capítulos, cada qual dividido em dois tópicos. O capítulo inicial concentra-se na análise do contexto histórico no qual o Marquês de Sade está inserido e como que esse contexto influencia ou não o seu pensamento. Dessa forma, é descrita a importância da filosofia das Luzes no século XVIII e também a importância da literatura libertina. Esse capítulo também reforça a idéia de que Sade, apesar de estar inserido no contexto iluminista e de adotar a estética da literatura libertina, o faz ao seu modo. Isso acaba por distanciá-lo dos próprios filósofos iluministas e dos demais autores libertinos.

Já o segundo capítulo concentra-se em uma reflexão sobre a importância do conceito de natureza no pensamento e na obra sadiana. Nesse sentido procuramos entender as inter-relações de Sade com os filósofos do século XVII (Thomas Hobbes em especial) e do século XVIII (Rousseau). O objetivo principal dessa discussão foi a de localizar o pensamento sadiano dentro de uma tradição filosófica que refletiu sobre o conceito de natureza.

O último capítulo da monografia dedica-se a examinar de que forma Sade promove seu ataque a Deus e como seu ateísmo se fomenta. Além disso, também é examinado o alcance das filosofias materialistas no pensamento ateu do marquês. Para isso foi indispensável fazer uma aproximação de Sade com La Mettrie e Holbach, seus contemporâneos materialistas e declaradamente ateus. $\mathrm{Na}$ finalização do capítulo tratamos do conceito e da primazia do Mal no pensamento sadiano como resposta da natureza à benevolência promovida pelo pensamento cristão.

Podemos inferir após a análise das obras e do pensamento sadiano, bem como as principais correntes filosóficas que o influenciaram, que o divino marquês foi responsável por um ateísmo, no mínimo, peculiar. O que denuncia isso, por exemplo, é sua extrema fúria contra a própria idéia de Deus. 
Sade se distingue dos ateus de sua época por estabelecer uma descrença "crente". Queremos dizer que o ateísmo sadiano, sua filosofia do Mal e a primazia da natureza formariam, na verdade, uma religião, um credo invertido. Sade substitui Deus pela natureza, mas nem por isso essa se mostra benevolente, é sim uma força de destruição em constante movimento e a origem de todos os vícios. $\mathrm{O}$ Mal impera por que é a forma que o libertino se percebe e atua no mundo, o Mal é o caminho da natureza.

Sendo o mundo e os homens criação e objeto de destruição da natureza, o que importa ao libertino é exceder-se em prazer. Sade se utiliza das filosofias materialistas para dar ao libertino um mundo que se rege pelo movimento, pela matéria. Os prazeres são descargas elétricas disparadas pelos corpos, e isso Sade aprende com os materialistas. A natureza basta a si mesma, já diz uma de suas personagens. Por isso mesmo, os homens bastam-se a si mesmos. Os fortes imperam sobre os fracos, o prazer é o único objetivo do homem.

Podemos considerar Sade uma espécie de anti-ateu. Isso não implica em dizer que Sade era, na verdade, um cristão enrustido, muito pelo contrário, como ele mesmo diz, a idéia de Deus é o único erro que ele não perdoa aos homens. Sade é um anti-ateu por não se portar como um. Nunca um ateu falou tanto de Deus como ele.

Criticar as crenças religiosas e atacar os costumes cristãos não é prerrogativa somente de Sade. Muitos atacam a Igreja e os preconceitos religiosos, mas a novidade que Sade imprime está em não somente atacar, mas promover como valor fulcral o Mal. O Mal é natural ao homem, o egoísmo, a destruição são os primeiros princípios da Natureza.

Esse ateísmo sadiano toma um ar quase teológico na sua obra. A filosofia do Mal de Sade é uma proposta inversa ao cristianismo, ou seja, o único Deus que o homem deve prestar honras é a si mesmo, ao princípio natural dentro de si que busca a qualquer custo o prazer. 